\title{
ARCHAEOMETRIC STUdies CONDUCTED AT THE RHODiApolis TheATRE
}

\author{
RHODIAPOLIS TIYYATROSUNDA YAPILAN ARKEOMETRİK ÇALIŞMALAR
}

\section{BANU ÖZDİLEK ${ }^{*}$}

\begin{abstract}
Rhodiapolis was a medium sized polis in the Eastern Lycian region, by the Mediterranean coast of Anatolia. Over the course of this 4 year excavation the theater which had been largely buried was exposed and became one of the few Lycian theaters that to date has been completely excavated. In consequence, new information was obtained concerning the theater architecture of the Lycia region and of the architecture of Anatolian Greco-Roman theaters. In this study, archeometric practices providing crucial technical support to archeology were employed in the investigation of the theatre. The archeometric study of the theatre enabled the accurate measurement of the theatre, its location within the thematic topographic map of the city and its surroundings with a scale of $1 / 5000$, the drawing of the stone plan and photogrammetric drawings of the analemma and the walls of the stage building of the theatre, determining the period, shape and the changes made to the theatre. In addition, the preservation statics, the architectural features, visual monitoring and the acoustic assessment in the Rhodiapolis Theater are discussed. Among the questions concerning theatres the question as to, "For how many people was this theatre constructed", the notional capacity of the theatre arises. Within the scope of this study because no formulated practical accurate method concerning theatre audience capacity has been recorded in the sources, nor in the texts concerning theatres to date, a formula was developed to measure the capacity of the seating.
\end{abstract}

Keywords: Rhodiapolis • Hellenistic Theatre • Roman Theatre $\bullet$ Lycia $\bullet$ Archeometry
Öz: Rhodiapolis; Anadolu'nun Akdeniz kıyısında, Doğu Lykia Bölgesinde, orta ölçekli bir polis'tir. Rhodiapolis Tiyatrosu'nda 4 yıl boyunca süren kazılar sonucunda, tamamen toprak altında olan bir tiyatro gün yüzüne çlkartılmıştır. Rhodiapolis Tiyatrosu, Lykia Bölgesi tiyatroları içerisinde tamamen kazılmış az sayıdaki tiyatro arasındaki yerini almıştır. Böylece gerek Lykia bölgesi tiyatro mimarisine gerekse Anadolu Greko-Romen tiyatro mimarisine yeni bilgiler sunmuştur. Bu çalışmada tiyatronun ortaya çıkarılmasında arkeolojiye en büyük teknik desteği veren arkeometri uygulamalarından yararlanmıştır. Yapılan arkeometrik çalışmalar, tiyatronun ölçme işlemleri, kentin ve çevresinin 1/5000 ölçekli tematik topografik haritas1nın alımı, tiyatronun taş planının ve analemma ve sahne binası duvarlarının fotogrametrik çizimlerinin yapılması, tiyatronun dönem ve şekil değișiklerinin saptanması şeklinde olmuştur. Ayrıca Rhodiapolis Tiyatrosu'nda korunmuşluk, statik, mimari özellikleri, görsel izleme ve akustik değerlendirmeleri ele alınmıştır. Tiyatrolar hakkında sorulan soruların başında, " $\mathrm{Bu}$ Tiyatro kaç kişiliktir” sorusu yani kapasite kavramı gelmektedir. Tiyatrolar hakkında bugüne kadar yazılmış kaynaklarda, kapasite hesabı hakkında pratik ve doğru bir formüle edilmiş bir yöntem bulunmaması nedeniyle, bu çalışma kapsamında tiyatroların kapasite hesaplamaları için bir formül geliştirilmiştir.

Anahtar Kelimeler: Rhodiapolis • Hellenistik Dönem Tiyatrosu • Roma Dönemi Tiyatrosu • Lykia • Arkeometri

* Yrd. Doç. Dr., Mustafa Kemal Üniversitesi, Fen-Edebiyat Fakültesi, Arkeoloji Bölümü, Hatay. ozdilek.banu@gmail.com

I would like to thank to Prof. Dr. Nevzat Çevik for beginning the Rhodiopolis excavations, his energy in building the infrastructure, project and organisation, to enable the completion of the theatre excavations within the short period of four years, Öğr. Gör. Süleyman Bulut for all of his efforts, and to all of my friends assigned to the Rhodiapolis excavation team.

Secondly I would like to thank Dr. A. İlhan Özdilek, who prepared photogrammetric drawings and gave support to mapping as a photographic survey engineer, who also renewed the theatre capacity calculation formula. 
"Archaeometric" applications within the scope of archaeological excavations generally begin during preliminary research and are conducted in phases, eg. practice, introduction, exhibition and even revision of finds in ongoing excavations, defining locations, identifications, recording, archiving, repairing, protection works, restitutions and restoration processes ${ }^{1}$. In this way, all measurement and identification studies supported through measurement conducted in planning and implementation phases for the purpose of determining and dating locations, dimension, shape, formal characteristics of finds are covered ${ }^{2}$.

The city of Rhodiapolis is situated over a hilltop in Antalya Province 3 (fig. 1), Kumlucu District, Sarıcasu Quarter, in a location facing the Mediterranean in the region of Eastern Lycia. It has borders with Arykanda to the north-west, Korydalla to the south-east, Gagai to the south-east, Limyra to the south-west and Olympos to the east (fig. 2). The settlement at Rhodiapolis is a medium sized Lycia city in terms of its area of construction and structures.

The history of the city dates back to the Bronze Age ${ }^{4}$ from the archaeological finds obtained from the Rhodiapolis Baths excavations ${ }^{5}$ (fig. 3).

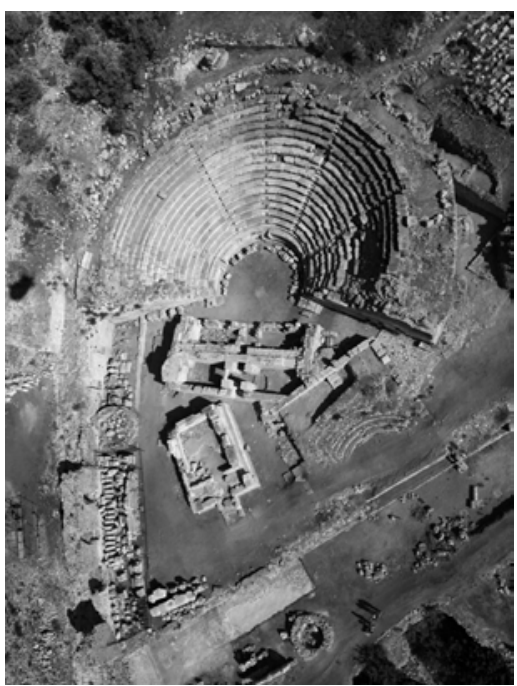

Fig. 1. Rhodiapolis Theater

The city of Rhodiapolis ${ }^{6}$ was established on peak of a hill and on the South facing slope extending downwards, over a very rugged terrain 7 . The theatre ${ }^{8}$ is situated south-east of the Acropolis hill where the ruins of the East-Roman (Byzantine) settlement stands, conspicuous today in the north of the city (fig. 4). The axis of the theatre opens in a south-easterly direction and because of this orientation, it receives sunshine all day long. During the construction of the theatre, a terrace wall was constructed one hundred meters in front of it and the area between the theatre and the agora was filled with soil. While there is a clearly visible portion of this retaining wall carrying Hellenistic Period masonry, this area was redeveloped into a two storeys agora during the Roman Period. Located at the centre of public structures, the theatre was constructed in

Özdilek - Tıbıkoğlu; Arkeometriye Giriş (forthcoming).

Akyol - Özdemir 2012; Duru 2003,193; Yalçın 2012, 39 ff.

Çevik et al. 2007, 59-67; Çevik et al. 2008a, 54-60; Çevik et al. 2008b, 1-18; Çevik et al. 2009a, 297-316; Çevik et al. 2009b, 50-61;

4 The city was dated to around the VIII ${ }^{\text {th }}$-VII ${ }^{\text {th }}$ centuries B.C., and is presumably dated for the first time to the Bronze Age following the investigation of a vessel found in the course of this study. Because it was found in a mixed context beneath the water pressure tower (castellum) of the baths, it is hard to provide an exact date for this handmade miniature vessel, having two horizontal handles, of a type which has been found elsewhere and has been dated from the Neolithic period to the Bronze Age. However this find was important in establishing a pre-Geometric period date for the city's foundation, through the find of a similar vessel in the city of Gagai, neighbouring Rhodiopolis. The example from Gagai was dated to the EBA II period. See: Çevik - Bulut 2008, 3.

Çevik et al. 2007, 59-67; Çevik et al. 2008a, 54-60; Cevik et al. 2008b, 3 ff.; Çevik et al. 2009, 231-260.

Cevik 2008b, 1-75.

Çevik et al. 2010b, 29-63.

Özdilek 2011; 2012. 


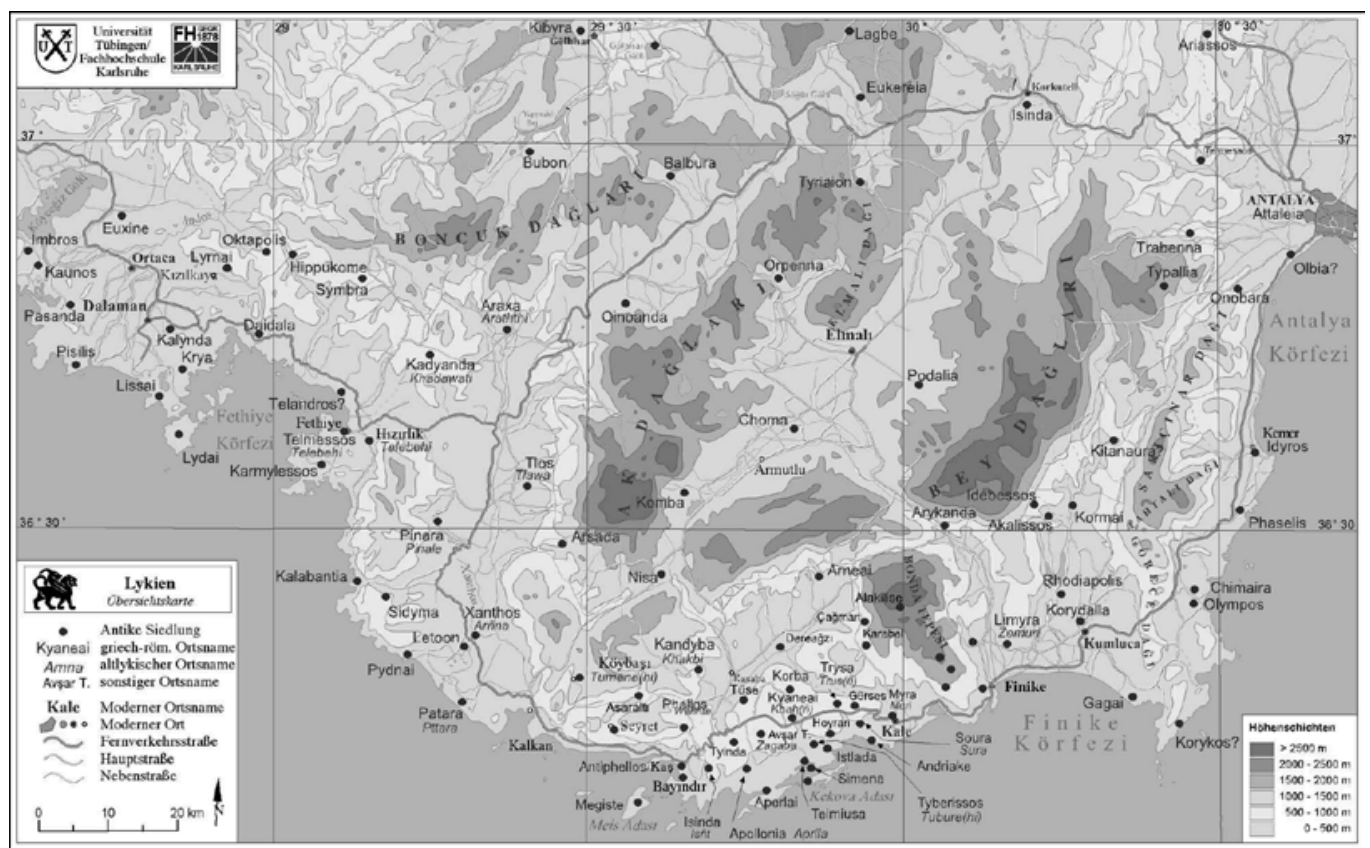

Fig. 2. Lykia Region

stone at the earliest in the Hellenistic Period. Other structures that have been dated to the Hellenistic Period include some parts of temples, a cenotaph and the aforementioned agora wall. Finding space in reconstruction work in the city centre was a big problem during the Roman Period (fig. 5). The theatre was the most remarkable public structure, and other public structures which were constructed in the Roman Period were built around it. The agora situated in front of the area where the theatre was constructed was redeveloped during the Roman Period and the monumental tomb of Opramoas was constructed on the area upstairs termed the Stoa of Opramoas. The eastern end of the stage was demolished in the Late Roman Period and a Meeting Hall was built over this area.

The Sebasteion of Hadrian, the Round Temple and the Asklepeion are located to the south and the Stoa is located to the west around the theatre. The bath is in the east of the city, the G structure to the south and the Temple to the north-west. The necropoli extend beside the roads of the city.

The excavation of the Rhodiapolis Theatre began in $2006^{9}$ and was completed in the course of 4 years work and study in $2009^{10}$. There are 32 theatres known within the region of Lycia ${ }^{11}$. Studies were initiated at nine of these 32 theatres and excavations were completed in eight of them. This number, less than one third of the total known is quite limited, and with this study, a new example has been added to those examples of fully excavated Lycian theatres. While significant new information has been provided within the area of research into the theatres of antiquity, together with accurate and authentic views of this theatre.

In particular the cavea area of the Rhodiapolis theatre, $70 \%$ of which has been exposed is well-protected, while the hyposkene and postskene parts of

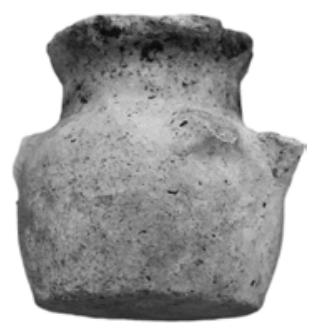

Fig. 3. Bronze Age Vessel

\footnotetext{
Çevik et al. 2007, 59-67; Çevik et al. 2008b, 1-19; Çevik et al. 2008a, 54-90; Özdilek 2010, 211 ff.

10 Özdilek 2010, 87 ff.

11 Özdilek 2011.
} 


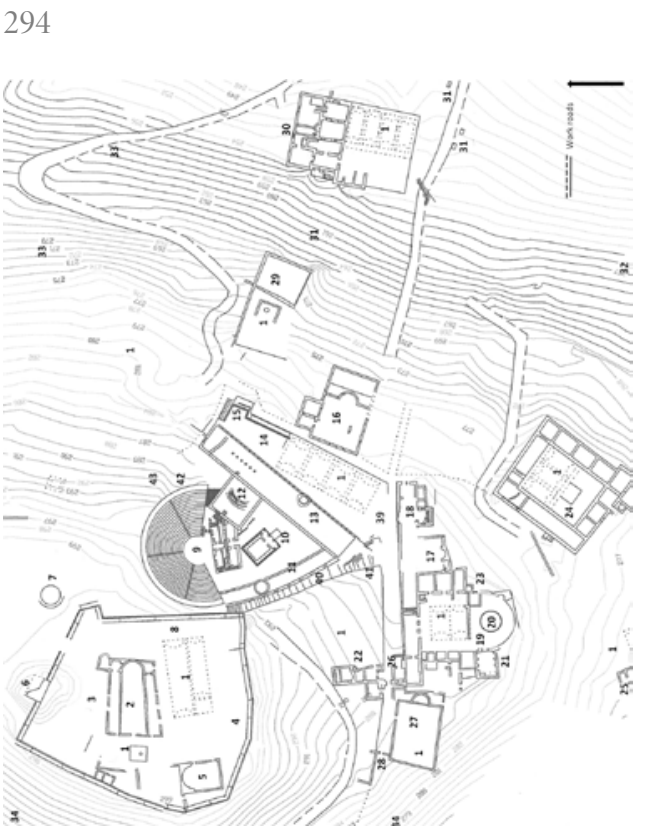

Fig. 4. Rhodiapolis City Map

the stage building are also in a well-protected state ${ }^{12}$ (fig. 6-7).

The building material employed in the construction of the theatre is local limestone. The cavea with lion's feet carved at end of rows is of fine workmanship (fig. 8-9). Polygonal masonry was employed in the construction of the rear analemma and isodomic masonry for the lateral analemma wall (fig. 10-11). Isodomic masonry was employed in the analemmata (fig. 12-13), hyposkene (fig. 14), proskene (fig. 15) and postskene (fig. 16), while the skene side wall was bonded with small rubble stones in the skenefrons in the first floor of the stage building and these were most probably clad in marble or covered and painted. Four of eight of the cavea lean against the slope and northern western analemma wall was faced with polygonal masonry (fig. 10). Entrance-exits to the theatre are provided by the eastern and western parodos and those leading from the basilica way enter and exit from the rear of the cavea. The cavea is divided into seven klimakes and six kerkides with the cavea consisting of one single section and eighteen rows (fig. 17). There are two seats termed "cella curilis" (fig. 18-19) in front of the cavea and a row in the shape of a throne-bench termed a "bisellum" (fig. 20) in the rear uppermost row. The upper section of the theatre was covered with canopy systems and these varied according to the period. It was covered with a baldachin during the Hellenistic Period (fig. 21) and by a velarium system during the Roman Period (fig. 22). The form of the orchestra, circular with a floor of compacted soil. The stage building is of two floors with the ground floor (fig. 23) and the architectural decoration in the Doric style. The hyposkene has a vault covering two rooms (fig. 24) and the postskene has also two rooms. The proskene has five gates (fig. 23), while the skene-frons has three gates. The front and rear "porta regea" gates of the stage building are in Ionic style and has lintels and jambs, while the other gates are in the Doric style. Important inscriptions were recovered from the theatre and in addition, the masonry of the cavea carries mason marks. As a consequence of all the archaeological work conducted it was determind that the first phase of the cavea was consstructed in the Late Hellenistic Period. It was then expanded in the second century A.D., while the stage building was constructed in the Early Roman Period and there were Middle, Late Roman-Byzantine Period phases of construction.

Following this general introduction to the Rhodiapolis Theatre, we can now pass on to archaeometric studies conducted within the scope of this research. The archaeometric studies conducted in the Rhodiapolis theatre were conducted employing the classical questionnaire,

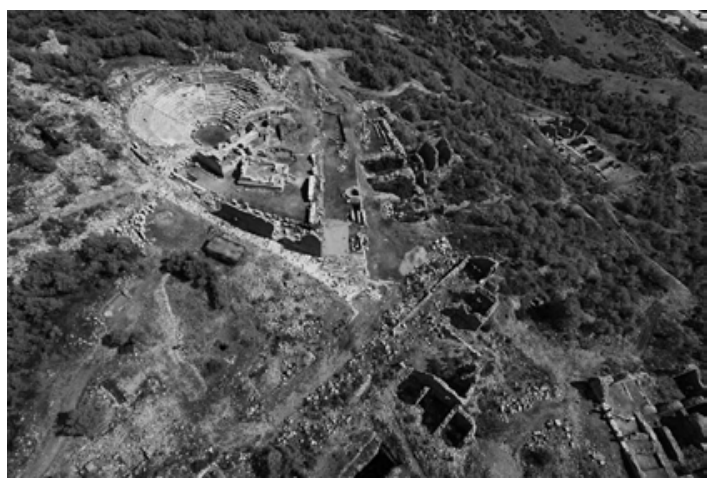

Fig. 5. Rhodiapolis Theater

12 Çevik 2012, 129-142; Özdilek 2012, 301-312. 
application and assessment applied to the subjects and under the rubric of the "Classification of Monitoring and degrees of Audibility". With these studies conducted through measurement procedures establishing: length, size, angle, slope, elevation, measurment coordinates and calculations, as in the recording of a topographic map, employing terrestrial and aerial photogrammetric measurements and drawings; with a new theatre capacity calculation employing a new mathematical method, mapping and building surveys.

Dating has been established through the assessment of archaeological finds and through the methody of analogy. Methods and techiques of chemical and physical analysis were not employed for dating through the physical properties of materials employed.

\section{1-Mapping Study}

(1:5000) scale, Thematic-Topographic-Archaeological mapping was made with a classical method, from the ground through using country, Triangulation and GPS network (fig. 4). After the completion of the excavation, the mapping of the theatre and its perimeter was carried out. Within this context, the physical dimensions of the theatre were established and the classical measurements of the opening were established.

\section{2- Measurement Procedures Performed in the Rhodiapolis Theatre}

The issue required to be specified within the scope of the archaeometric studies conducted in the Rhodiapolis Theatre is what are the types of these measurements: (distance-angle-slope) and for what purposes could they be employed (restitution-restoration). Measurements and drawings to be employed for restitution and restoration and "introduction" measurements, to be taken as a basis for the information given for the general identification of the theatre were taken as "engineeringarchitecture measurements". The detail dimensions to be measured and the sensitivity limits of the measurements to be made for the correct identification of theatres should be given in $\mathrm{cm}$.- $\mathrm{dm}$ sensitivity (height-length-width-depth), while wall dimensions should be given in decimeter ( $\mathrm{dm}$ ) sensitivity and these criteria will be accurate, to a degree more than sufficient for the introduction. For example, this degree of sensitivity in the measurement of the architectural elements used in the stage building and the cavea of the Rhodiapolis theatre can be reduced to $\mathrm{cm}$ dimension.

The measurements obtained from cavea; the elevation of the working area was obtained according to the height plan (Plan Elevation).

a-Cavea (fig. 25): Clearance of the lower spring end points of the cavea is 8,85 meters. The cavea lower spring diameter is 10 meters while the cavea lower spring length is 20,14 meters. The clearan-

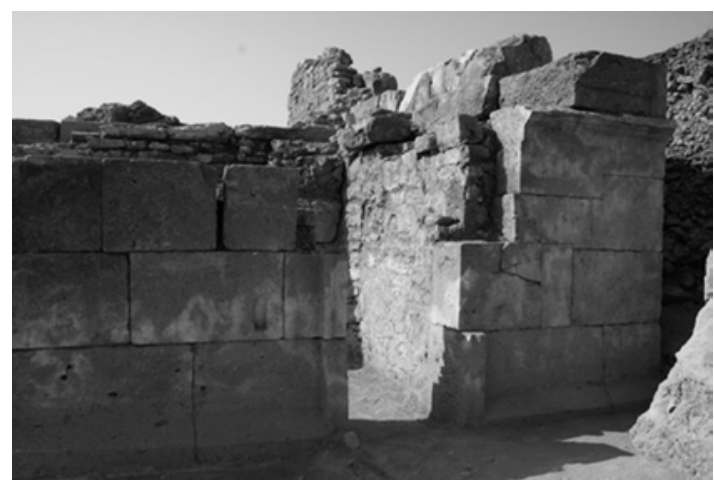

Fig. 6. Rhodiapolis Theater, skene

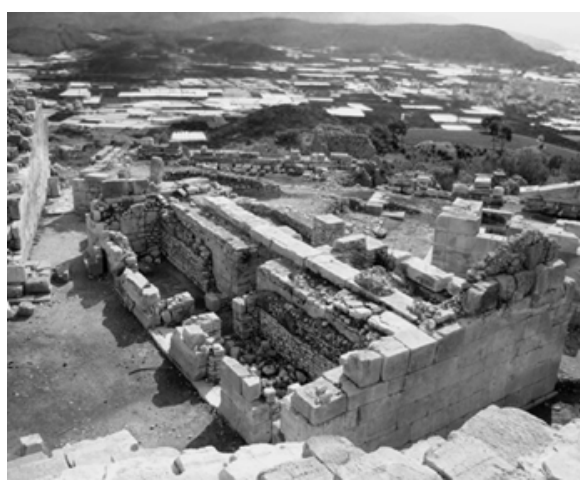

Fig. 7. Rhodiapolis Theater, proskene 

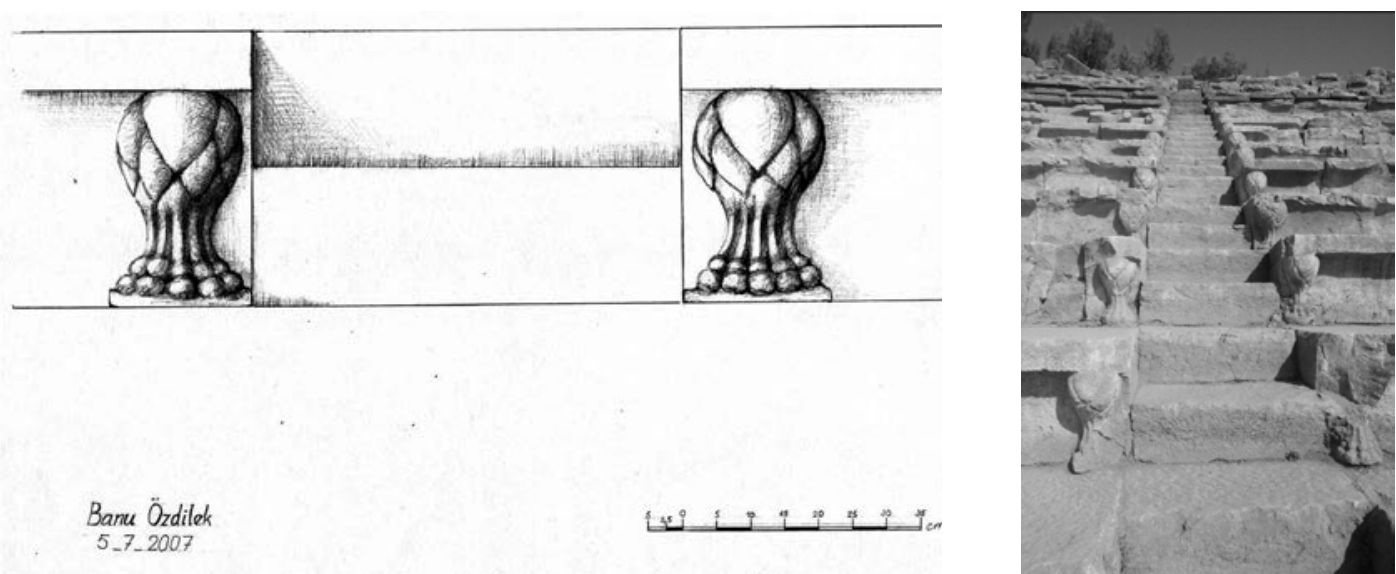

Fig. 8-9. Rhodiapolis Theater, rows with lion feet

ce of the upper spring end points of the cavea is 39,2 meters, while the cavea upper spring diameter is 34 meters. The cavea upper spring length is 65,3 meters. The ground protected height of the western analemma wall of the cavea is 6,24 meters, while the ground protected height of the eastern analemma wall is 10,52 meters.

The slope of cavea is accordingly different in the west and east. Slope measured from second kerkides in the west is 34 degrees and slope measured in the second kerkides direction is 30 degrees. The reason why the slope in the constructed section of the cavea over filling material was to reduce and disperse the load. The horizontal length of cavea differs one from another and the reason for this asymmetric form of cavea is that it does not lean against the bedrock. The horizontal length of the cavea in the direction of the second klimakes in the west is 13,18 meters, while the horizontal length of the second klimakes in the direction of the cavea in the east is 14,35 meters.

b-Analemma: Directions of two analemma surrounding in a planar way the eastern and western sides of the cavea interesect in the orchestra with 210 central angles. The length of the eastern analemma wall is 15,27 meters and its ground protected height is 11,52 meters. The length of the western analemma wall is 14,93 meters and its ground protected height is 6,24 meters.

c-Parodos: The area between the eastern parodos and the meeting hall is the area where the parados narrows and clearance here is 1,57 meters. The distance between the stage building and the eastern parados is 2,28 meters. The length of the western parodos is 4,50 meters. Clearance between analemma from the corner of the stage building is 2,20 meters and it is 3,60 meters in internal section. There is a 20 degrees angle between the facade of the stage building and the analemma wall.

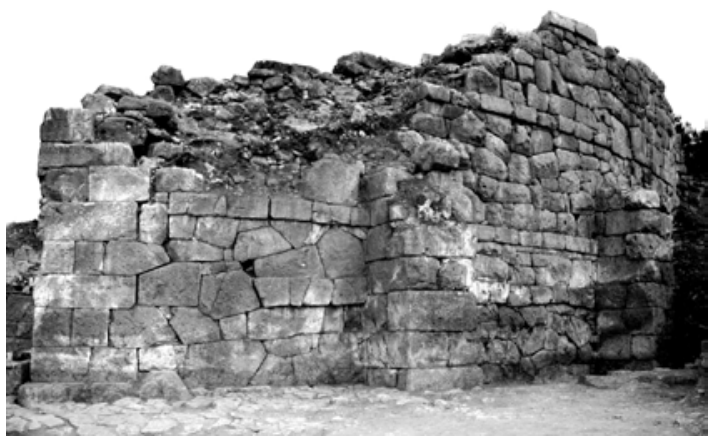

Fig. 10. Rhodiapolis Theater, rear analemma
d-Rows: The cavea has eighteen rows. The dimensions of the lowest row are different from one another. Its height is 0,40 meters and its depth is 0,36 meters. Length: Each block is of a different length.

From the lower part, the height of the second bench and others are 0,42. Their depths are approximately $0,78 \mathrm{~m}$ and the widths vary from 0,77 meters to 0,90 meters.

e-Klimakes-kerkides: The cavea is divided into 

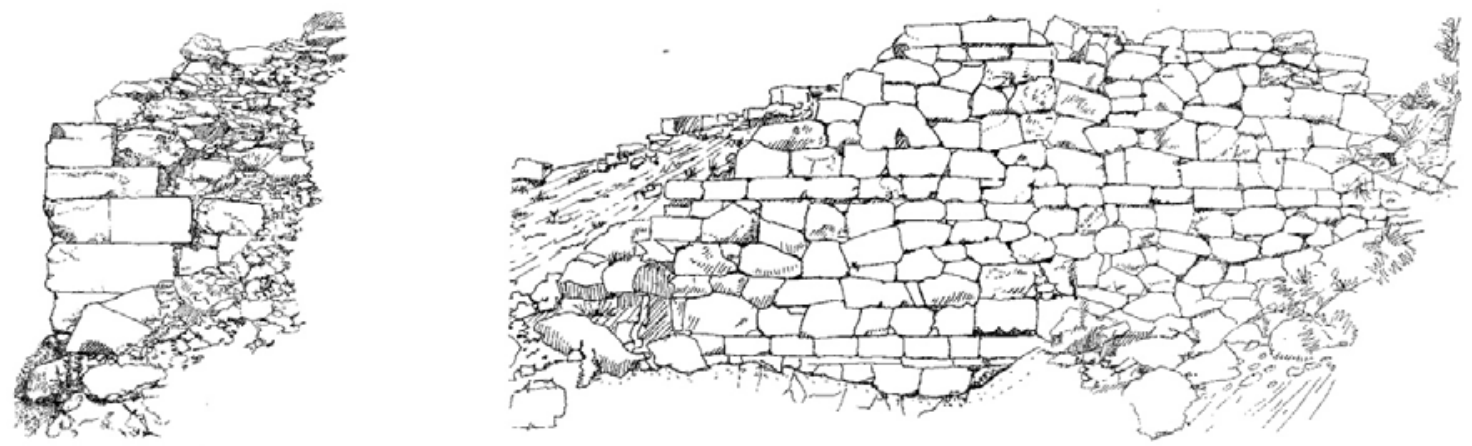

Fig. 11. Rhodiapolis Theater, rear analemma

seven klimakes and six kerkides (fig. 25).

Klimakes: The width of the stairs is approximately 0,58 meters; the depth 0,32 meters and height 0,20 meters.

Gates opened to orchestra in cavea: The width is 0,88 meters (fig. 18).

Cavea podium wall: The total height is 0,87 meters.

f-Diazoma: There is one diazoma at the back in the cavea. The width of the diazoma is 2,30 meters. When bisellum seats at the back row of cavea are located, the remaining diazoma clearance is 1,28 meters (fig. 25).

g-Orchestra: It has a diameter of 10,32 meters. Its form is round and the length of the orchestra between the proskene and the cavea is 10,17 meters (fig. 25).

h-Skene: The skene comprises two floors together with ground. Its length is 16,63 meters and width is 8,90 meters. The most protected part of the skene is the western part and height is 4,98 meters (fig. 24).

I-Proskene: The proskene has five gates. The width of the gate at the eastern end is 0,70 meters. The width of the second gate is 0,90 meters; of the middle gate 1,52 meters; of the fourth gate is 1,10 meters and the width of fifth (westernmost) gate is 0,73 meters. The height of the proskene is 2,37 meters.

j-Hyposkene (fig. 14): Its height is 2,76 meters with a width of 1,96 meters. Hyposkene eastern room is two rooms wide with a height excluding the vault of 2,17 meters. The hyposkene western room is two meters wide with a height of 2,17 meters.

k-Postskene (fig. 16): East back room is 3,30 meters wide and its height is 2,28 meters. West back room is 3,20 meters wide and 4,98 meter high.

1-Skene Eastern Side wall (fig. 26): While the side walls of the stage building were of a rectangular shape during the first construction phase, its symmetry was subsequently deformed as a portion of the meeting hall was constructed over the eastern wall. The length of the wall is 6,40 meters.

m-Skene Western Side wall (fig. 24): Its length is 7,95 meters.

\section{3-Photogrammetric Applications Performed in the Rhodiapolis Theatre}

Aerial photos were taken from a helicopter, from a model helicopter and from a ballon at the end of each excavation season and prior to commencement of excavation, within the program of aerial 


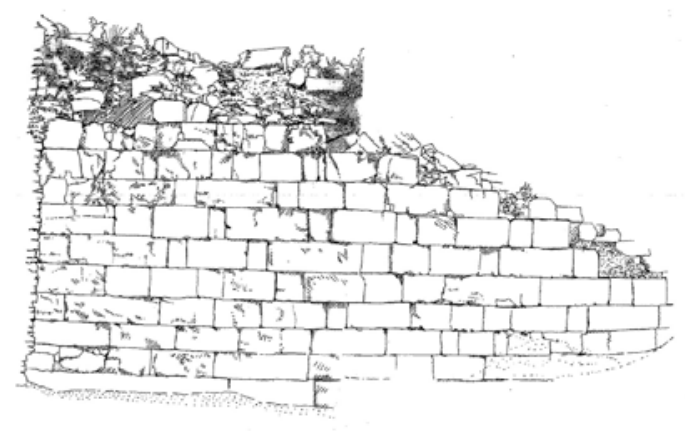

Fig. 12. Rhodiapolis Theater, west analemma

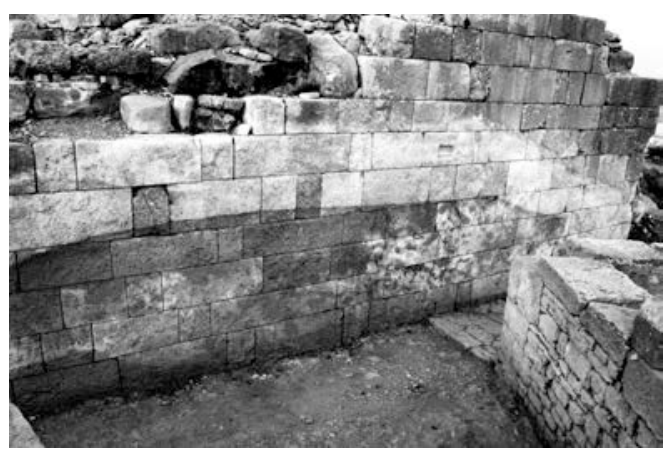

Fig. 13. Rhodiapolis Theater, east analemma

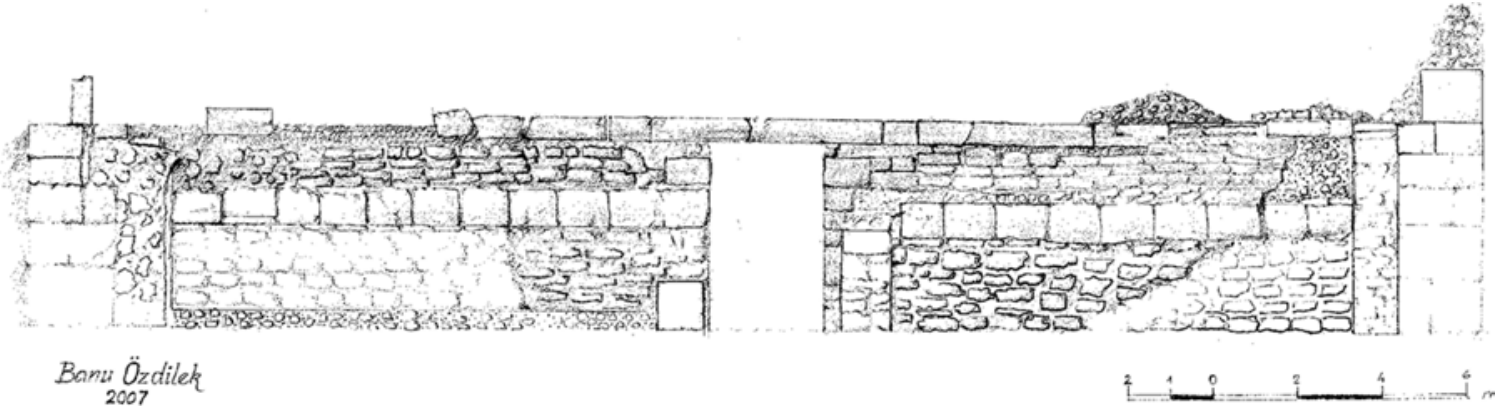

Fig. 14. Rhodiapolis Theater, hyposkene

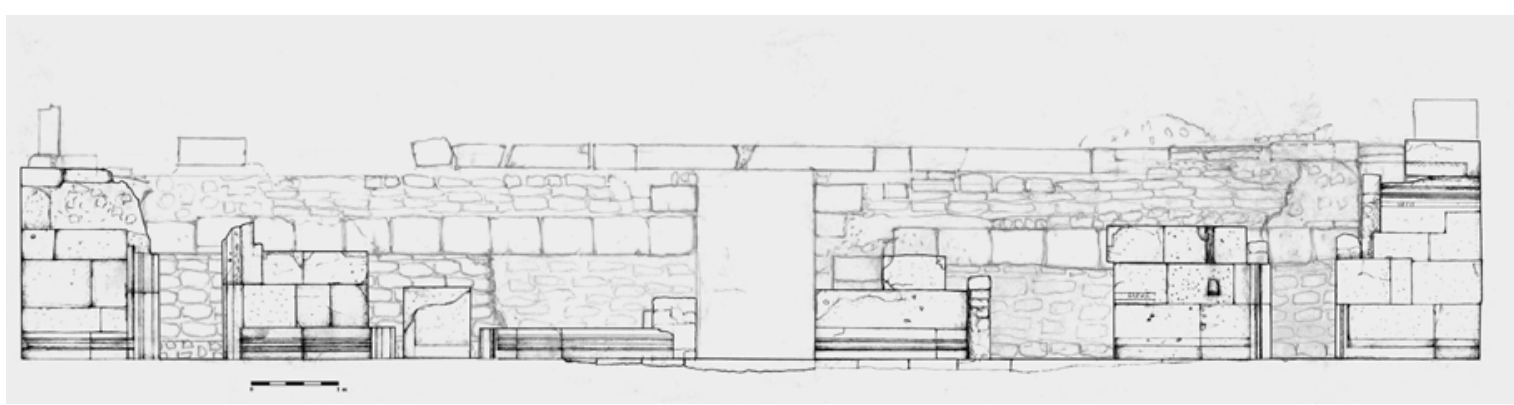

Fig. 15. Rhodiapolis Theater, proskene

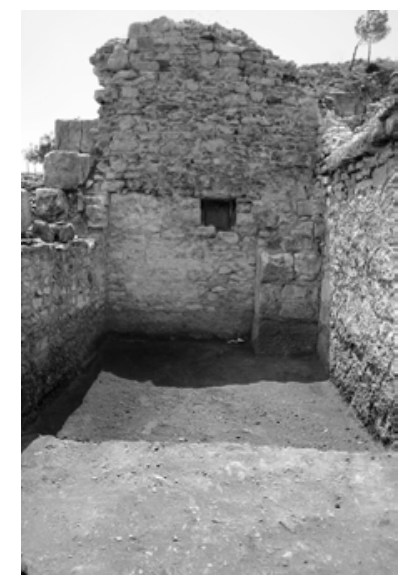

Fig. 16. Rhodiapolis Theater, hyposkene

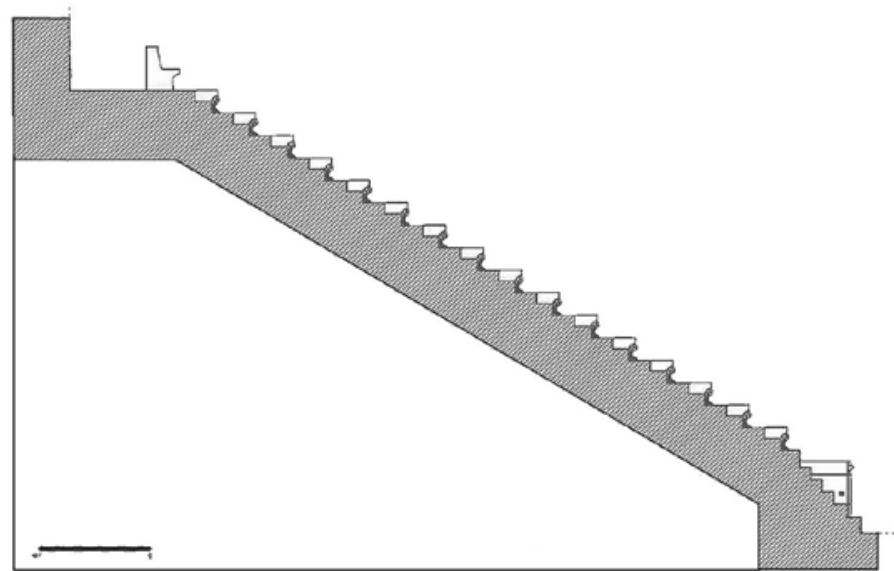

Fig. 17. Rhodiapolis Theater, cavea 


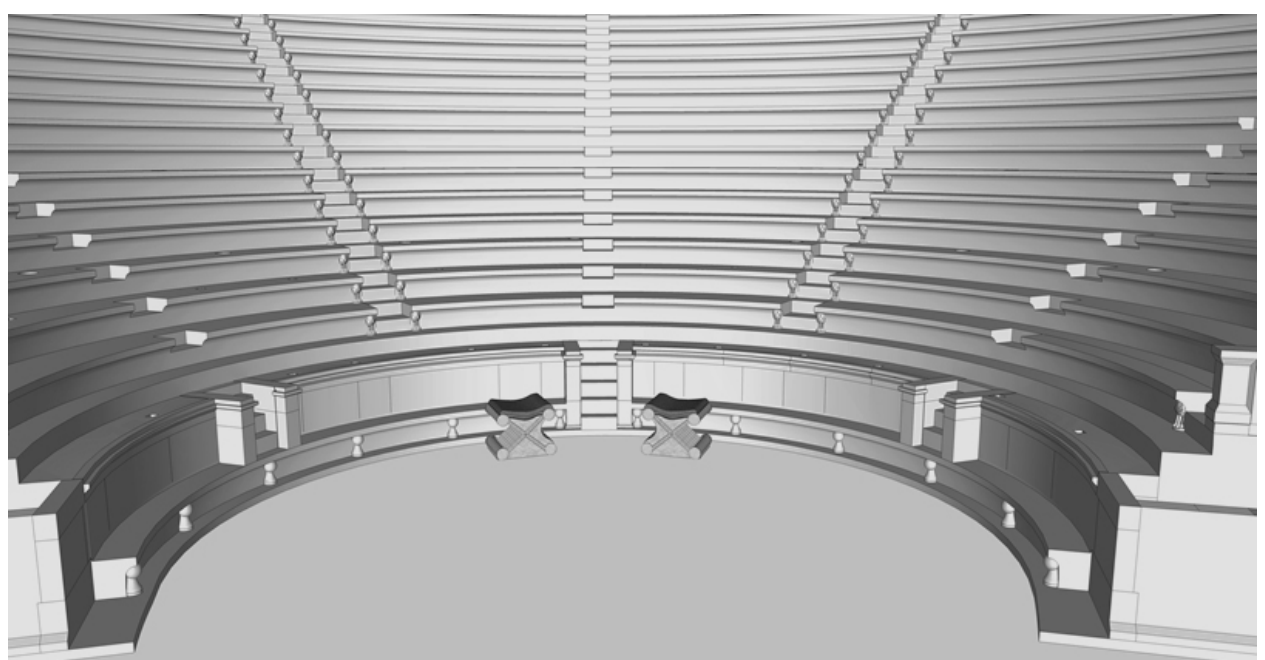

Fig. 18. Rhodiapolis Theater, cavea
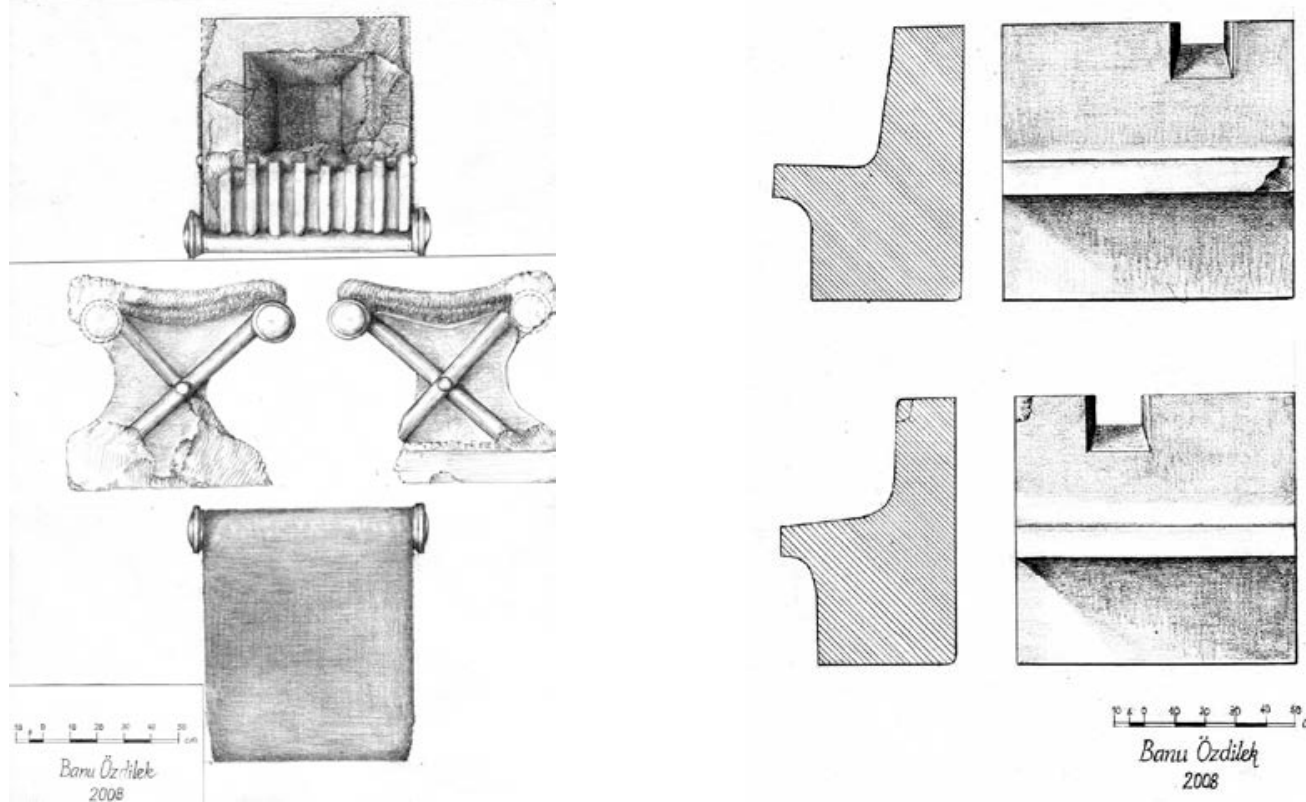

$\frac{\text { Banu Ozdiled }}{2008}$

Fig. 19-20. Rhodiapolis Theater, cella curilis

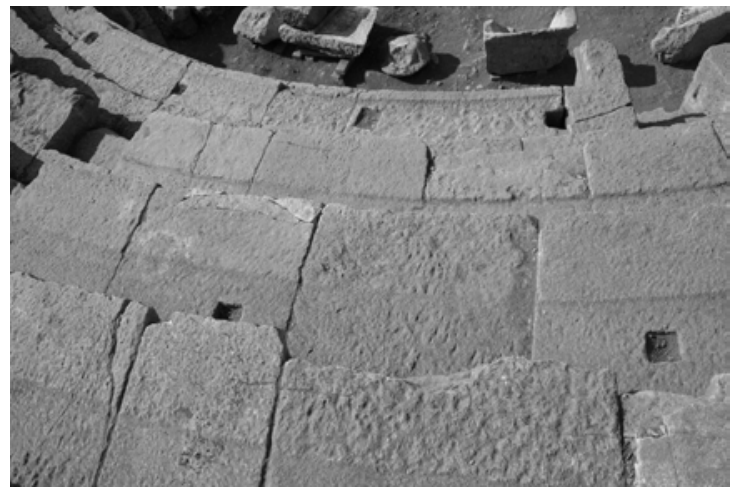

Fig. 21. Rhodiapolis Theater, baldachin

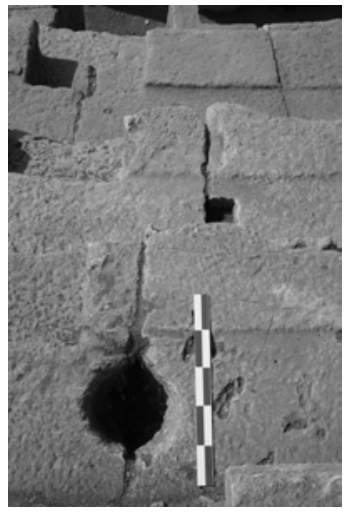

Fig. 22. Rhodiapolis Theater, velarium 


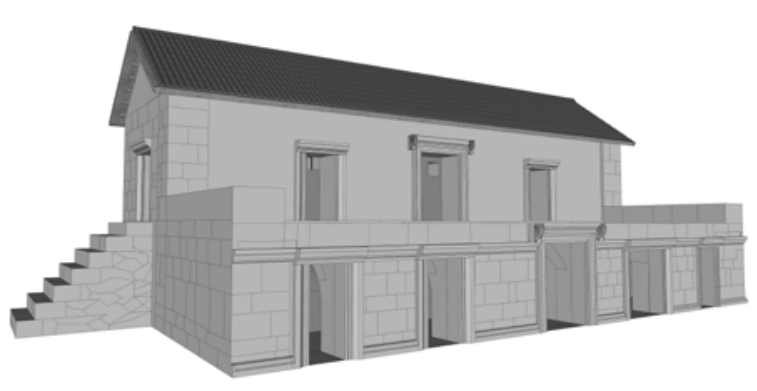

Fig. 23. Rhodiapolis Theater, skene

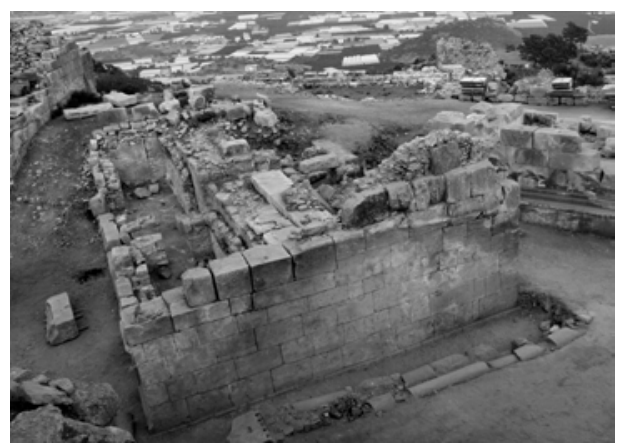

Fig. 24. Rhodiapolis Theater, skene

and terrestrial photogrammetry of the Rhodiapolis Theatre (fig. 1). The stone plan was made at 90 degrees from vertical aerial photos of the theatre (by eliminating "point drifts") (fig. 27). The general layout of the theatre and its perimeter, manual plan drawings in stage building, cavea and locations around it were made by eliminating "point drifts" that occurs from height difference proximate to 90 degrees from vertical aerial photographs taken from the air. The lateral and rear analemma walls and skene lateral wall were drawn from terrestrial monoscopic and stereoscopic photographs. The whole cavea of the theatre was recorded with panoramic photograhs.

\section{4-Acoustic Evaluation in Different Areas of the theatre}

Acoustic evaluation was to be conducted since the ground floor of the stage building of Rhodiapolis Theatre as protected, does not reflect the acoustic properties of the stage building constructed on two floors. For this reason the archaeometric measurement result compiled electronically by Irkl 1 Erylldız in earlier times provides information about the current state ${ }^{13}$. In addition to these measurements, a test known today as a hearing test has been developed and both measurements were established. Although these results overlap, it fails to provide acoustic information of Rhodiapolis Theatre in the Roman period.

Method Description: Firstly, each of the six kerkides of the theatre similarly starts from orchestra below and is divided into horizontal lower slice of three rows each and extending towards the audience diazoma above. These slices are numbered from one to six by starting from the right (west) and at the same time, trial slices to which the questionnaire is applied will start from one below and will be numbered again upwardly, up to six. The kerkides plans were prepared in separate parts in this way so as to be distributed to the selected subjects.

As a second part; 36 students with ability and no hearing problems were selected to participate in the study being taught with tests to distinguish their hearing quality ranging from "GoodMedium-Low" (similar to the methods used in classic hearing control).

As a third part; female and male voices were listened to reading a dialogue, text and to music as live subjects several times. This experiment was undertaken from the lowest row to the highest row of the theatre. It is understood that the element to be taken as a basis for distinguishing in the evaluation of the audibility is that sounds-characters and syllables in words are selected are entire and complete and the differences between notes are wholly perceived and distinguished and ranked (Good-Middle-Low).

Application, the fourth part; the students will sit in the middle row of kerkides slice in a three

13 Eryldiz 2006, 281-298. 
seat row and listen three times to the words and recorded music, also changing their places three times within the kerkides. The evaluation of that slice will be specified so that the benches in the plan will be indicated and numbers supplied through the test, "three=good, two=middle, one=weak", will be assessed and noted in the questionnaire plan. This process is then continued, repeating the same process for an upper slice.

Evaluation as final process: The average value of each slice will be determined and hearing limits will be determined according to this average. From bottom to top, in other words, beginning from the full point; "The good hearing limit is between 18-14, (for example: 3 points by 6 persons equals 18 points) "The good to middle hearing limit point = between 14-18" (for example: 3 points by 2 persons +2 points by 4 persons $=14$ points). "The medium to low hearing limit point $=$ between 8 0 " (for example: 2 points by 2 persons +1 point by 4 persons $=8$ points). The overlap in the limit line has been considered for the balancing of the line (fig. 28).

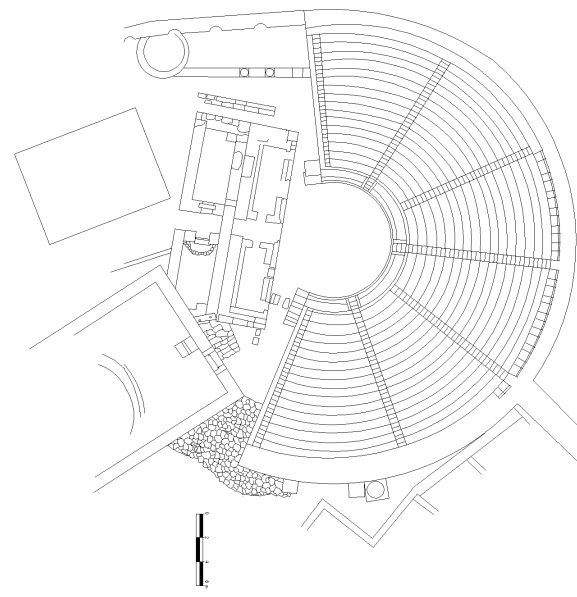

Fig. 25. Rhodiapolis Theater

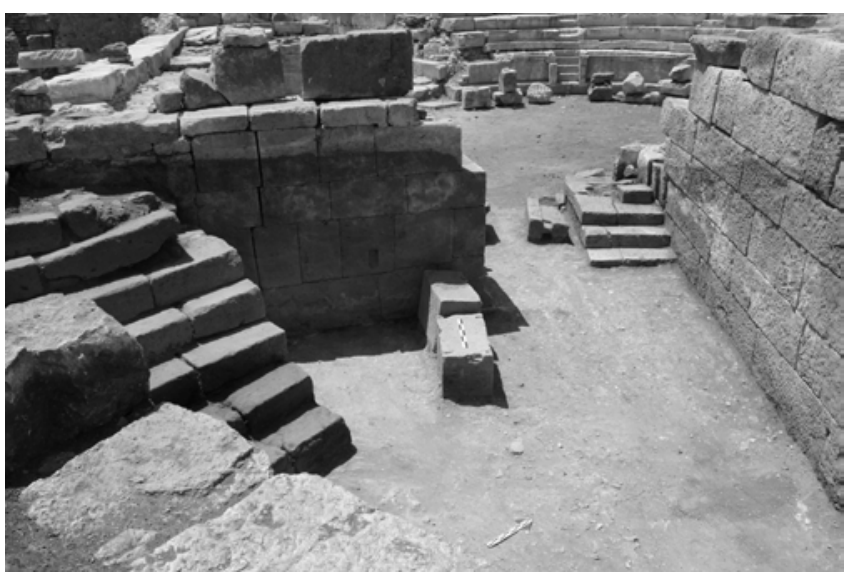

Fig. 26. Rhodiapolis Theater, west analemma

\section{5- Determination of the Visual Monitoring Degree within the theatre}

Method Description: The factors in this test to be taken forming the basis for this evaluation concern the visibility of facial and bodily lines and the degrees of visibility and if the mimes and body language are perceived clearly. The elements affecting this are the distance between the perspective and the stage, the angle made by the horizontal position of perspective towards stage (from the top, an oblique view) and the size of the angle to the middle axis of stage is to be taken as a basis (from the front-sides). As explained above, questionnaire will be applied as only formed by three elements (by considering the distance, the vertical angle and the lateral angles) and is evaluated. The relative importance of these elements in these evaluations will be explained through sampling (fig. 29).

\section{6- Construction of Hillside Settlement Limit in Hellenistic Theatres with Contour Curves and Cavea Contour Construction of Surface}

Solution of this problem is to apply directly the solution method of "construction of inter sections curve created with interceptions of different surfaces in elevated projections of geometry". In our example, one of the said surface is earth and this is present in the topographic map made at the beginning of this work. And the other is the internal surface of the cavea, in other words, rows are created by themselves and they are known level slopes; as a result of its nature, this is determined 

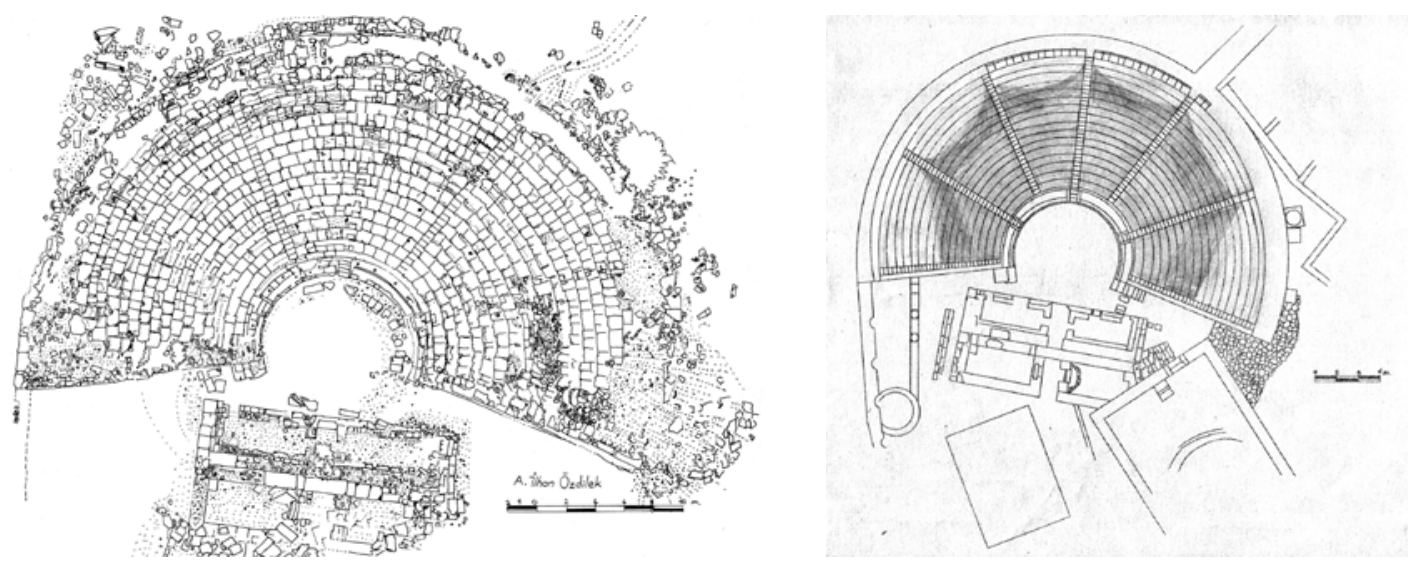

Fig. 27-28. Rhodiapolis Theater
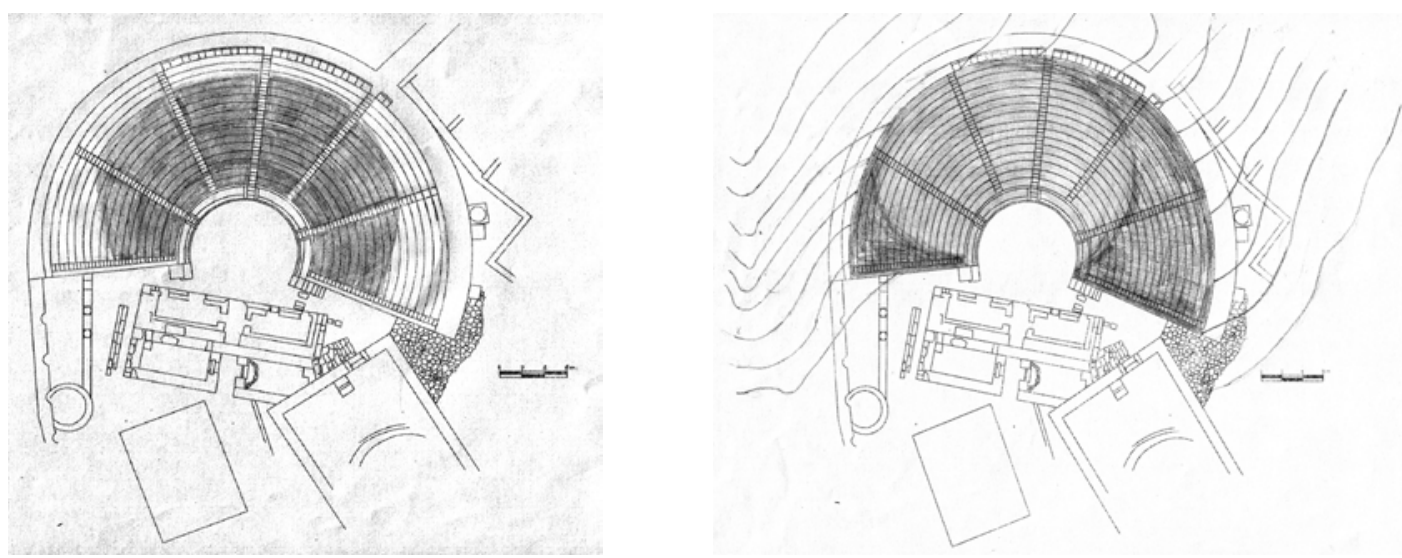

Fig. 29-30. Rhodiapolis Theater

with contours in the map and our example is present in the map (conducted within the scope of archaeometric studies). And the other one is the cavea internal surface (in contour nature) is defined with continual benches in the same level. Required limit-inter section curve is the intersection of the same elevation height curves on each of both surfaces (fig. 30).

\section{7-Calculation of the Capacity of Theatres}

Description of the new method applied: One of the questions frequently raised about ancient theatres is undoubtedly the capacity-the number of the audience seated within the ancient auditorium. This figure at the same time provides us with indications concerning the number of inhabitants of the city where the theatre is located. To date a myriad of methods have been proposed to calculate the capacities of ancient theatres ${ }^{14}$. During these studies, I developed and applied a method which reduced the number of measurements and the calculation procedures to an extremely simple level and which is a method having a sound mathematical basis.

Essence of the method; to determine the audience capacity from the total bench length in the theatre by dividing into the length of the rows the seat space of a single person.

The total length of the rows in the cavea is calculated in this way: Half of the total of the low row (the shortest) length and the upper (the longest) row length provides the length of a row of average length. When we multiply this length by the number of rows of the cavea, total row length of the

14 Bingöl 2005, 149; Sear 2006, 25 ff. 
cavea is determined. When the width of the seat of one member of the audience sits is considered to be $0,50 \mathrm{~m}$, the audience capacity of the theatre is found by dividing the cavea total row length from the meter type into $0.5 \mathrm{~m}$, in other words half the number of it.

The lowest row length in meters + the highest row length in meters divided two times by eighteen rows multiplied by $0,5=1,538$.

The number following this calculation for the Rhodiapolis Theatre provides an audience of 1,538 persons, rounded to the nearest one hundred; gives an audience capacity result of $=1,500^{15}$.

Morphological considerations, the conditions of the place where theatres have been constructed, inevitably entails deviation from any standardized conventional structural shape. In some theatres the traditional structural form, in the course of its expansion may deviate from the norm, and in such cases, the calculation of these addition sections is made employing this same method, the sum of which is then added to the capacity determined for the main structure established with the method given above. 


\section{List of Figures:}

Fig. 1. Excavation archive.

Fig. 2. Universtät Tübingen.

Fig. 3. Excavation archive.

Fig. 4. E. Akalın-S. Çoşgun- A. İ. Özdilek. Excavation archive.

Fig. 5. Excavation archive.

Fig. 6. Excavation archive.

Fig. 7. Excavation archive.

Fig. 8. B Özdilek.

Fig. 9. Excavation archive.

Fig. 10. Excavation archive.

Fig. 11. A. İ. Özdilek.

Fig. 12. A. İ. Özdilek.

Fig. 13. Excavation archive.

Fig. 14. B. Özdilek.

Fig. 15. B. Özdilek.

Fig. 16. Excavation archive.

Fig. 17. B. Özdilek.

Fig. 18. H. O. Tıbıkoğlu.

Fig. 19. B. Özdilek.

Fig. 20. B. Özdilek.

Fig. 21. Excavation archive.

Fig. 22. Excavation archive.

Fig. 23. H. O. Tibıkoğlu.

Fig. 24. Excavation archive.

Fig. 25. B. Özdilek.

Fig. 26. Excavation archive.

Fig. 27. A. İ. Özdilek.

Fig. 28. B. Özdilek.

Fig. 29. B. Özdilek.

Fig. 30. B. Özdilek. 


\section{BİBLIYYOGRAFYA}

Akyol - Özdemir 2012

Bingöl 2005

Çevik et al. 2007

Çevik et al. 2008a

Çevik et al. 2008b

Çevik - Bulut 2008

Çevik et al. 2009a

Çevik et al. 2009b

Çevik et al. 2009c

Çevik et al. 2010a

Çevik et al. 2010b

Çevik 2012

Duru 2003

Erylddı 2006

Özdilek 2011

Özdilek 2012a

Özdilek 2012b
A. A. Akyol - K. Özdemir, "Türkiye'de Arkeometrinin Ulu Çınarları Prof. Dr. Melek Özer ve Prof. Dr. Şahinde Demirci'ye Armağan”. Eds. A. A. Akyol - K. Özdemir, İstanbul (2012).

O. Bingöl, Magnesia ad Meandrum on the Meander: Theatron, Magnesia Ad Maendrum Monografileri I. İstanbul 2005.

N. Çevik, S. Bulut - İ. Kizgut, "Excavations at Rhodiapolis in 2006: The First Campaign”. ANMED 5 (2007) 59-67.

N. Çevik, İ. Kızgut - S. Bulut, "Excavations at Rhodiapolis in 2007". ANMED 6 (2008) 54-60.

N. Çevik, S. Bulut - İ. Kızgut, "Rhodiapolis Kazılarında İlk Yıl: 2006". KST 29-2 (2008) 1-18.

N. Cevik - S. Bulut, "The rediscovery of GAGAE/GAXE in the southeast corner of Lycia. New finds from the total surface surveys". Adalya XI (2008) 1-41.

N. Çevik, İ. Kızgut - S. Bulut, "Rhodiapolis 2007 Yılı Kazıları". KST 30-4 (2009) 297-316.

N. Çevik, İ. Kizgut - S. Bulut, "Excavations at Rhodiapolis 2008". ANMED 7 (2009) 50-61.

N. Çevik, İ. Kızgut - S. Bulut, "Rhodiapolis Baths: The First Evaluation Following the Excavations and Its Contribution to the Knowledge on Lycian Baths Architecture and Technique”. Adalya XII (2009) 231-260.

N. Çevik, İ. Kızgut - S. Bulut, "Rhodiapolis 2008 Kazıları". KST 31 (2010) 209-230.

N. Çevik, İ. Kizgut - S. Bulut, "Rhodiapolis, as a Unique Example of Lycian Urbanism”. Adalya XIII (2010) 29-63.

N. Çevik, "A First Report Following The Excavation Of the Theatre at Rhodiapolis”. Eds. F. Masino-P. Mighetto-G. Sobra, Restoration and Management of Ancient Theatres in Turkey. Italy (2012) 129-142.

G. Duru, "Anadolu Arkeolojisi'nde Metrik ve Normatif Yaklaşımlar". Eds. O. Erdur - G. Duru, Arkeoloji: Niye? Nasıl? Ne İçin? İstanbul (2003) 193-199.

D. I. Eryldiz, "The Acoustic Properties of Ancient Theatres: Computer Simulation and Measurements". Eds. K. Dörtlük, B. Varkıvanç, T. Kahya et al., III. Likya Sempozyumu. Antalya (2006) 281-298.

B. Özdilek, Rhodiapolis Tiyatrosu ve Lykia Tiyatroları. Yayınlanmamış Doktora Tezi, Akdeniz Üniversitesi. Antalya 2011.

B. Özdilek, Lykia'da Gün Yüzüne Yeni Çıkartılan Rhodiapolis Tiyatrosu. Fethiye 2012.

B. Özdilek, "Rhodiapolis Örneğinde: Tiyatro Sahne Binalarında anlamatanımlama-değerlendirme sorunları ve çözümleri ile ulaşılan sonuçlardaki, doğruluk riskleri üzerine, kuramsal yöntemsel bir çalışma”. Eds. K. Dörtlük, T. Kahya - R. B. Seyhan et al.,Uluslararası Genç Bilimciler Buluşması I. Anadolu Akdeniz Sempozyumu 2009. Antalya (2012) 301-312. 
Özdilek - Tıbıkoğlu 2015

Sear 2006

Yalçın 2012
A. İ. Özdilek - H. O. Tıbıkoğlu, Arkeometriye Giriş. (Yayın aşamasında) 2015.

F. Sear, Roman Theatres an Architectural Study. Oxford 2006.

Ü. Yalçın, "Neden Arkeometri". Eds. A. A. Akyol - K. Özdemir, Türkiye'de Arkeometrinin Ulu Çınarları Prof. Dr. Melek Özer ve Prof. Dr. Şahinde demirci’ye Armağan. İstanbul (2012) 39-41. 